\title{
IMPLEMENTASIKURIKULUM 2013 PADA MADRASAH TSANAWIYAH NEGERI (MTSN) MODEL MAKASSAR
}

\author{
The Implementation of Curriculum 2013 in MTSn Model Makassar
}

\author{
Hamriah \\ Universitas Islam Negeri Alauddin Makassar \\ dpk pada STAI DDI Makassar \\ J1. Sultan Alauddin No. 36 Samata Gowa \\ Email:hamriahthaha@yahoo.co.id
}

\begin{abstract}
Abstrak
Penelitian ini bertujuan untuk mengetahui bagaimana pemahaman guru Madrasah Tsanawiyah Negeri Model Makassar terhadap Kurikulum 2013? dan faktor pendukung dan penghambat implementasi Kurikulum 2013 tersebut serta solusi bagi implementasi kurikulum tersebut? Penelitian kualitatif ini menggunakan teknik observasi, wawancara dan dokumentasi dalam melalukan pengumpulan data. Hasil penelitian menunjukkan bahwa implementasi kurikulum 2013 di MTsN Model Makassar belum menunjukkkan totalitas diantara faktor penghambatnya adalah kurangnya buku pengangan bagi guru mata pelajaran, sarana dan prasarana pembelajaran. Solusi madrasah terhadap implementasi kurikulum tersebut salah satunya adalah dengan melakukan pelatihan kurikulum 2013 bagi guru internal madrasah.
\end{abstract}

Kata kunci: implementasi, kurikulum, madrasah

\begin{abstract}
Abstrak
Research aims to know the level of comprehension andskill of Madrasah TsanawiyahNegeri Model Makassar teachers on curriculum 2013 and factors that support and inhibit its implementation. This qualitative research collected data through observation, interviews and documentation. The result shows that MTSN model Makassar teachers has notfully implemented curriculum 2013 due to unavailability of textbooks, and unsupported learning infrastructure. One of the solutions is to train the teachers on curriculum 2013.
\end{abstract}

Keywords: implementation, curriculum, madrasah

\section{PENDAHULUAN}

1 pa yang sebenarnya melatarbelakangi kemauan pemerintah merombak kurikulum? Salah satu alasan yang dikemukakan adalah adanya anggapan bahwa kurikulum yang berlaku saat ini, yaitu KTSP, dinilai gagal. Lalu yang menjadi pertanyaan adalah betulkah KTSP gagal? Kalau dinilai bermasalah dimana letak permasalahannya? Apakah hasil ujian nasional peserta didik 5 tahun terakhir tidak dijadikan sebagai parameter keberhasilan kurikulum yang berlaku? Pada tahun pelajaran 2012/2013 menunjukkan angka kelulusan peserta didik tingkat SMA/MA mencapai 99,48\%. Sementara itu Wakil Ketua DPR RI Priyo Budi Santoso mengatakan, hasil UN secara kuantitatif perlu diapresiasi. Namun demikian, sekalipun secara nasional angka kelulusan meningkat, akan tetapi apakah itu otomatis secara mutu, kualitatif juga sudah ikut naik spektakuler, itu perlu diuji dengan waktu dan perlu ada pembenahan," ujar Politisi Golkar itu (Santoso, Tribun 24/05/13).

Selain itu, kurikulum 2013 dinilai juga tidak melibatkan komponen utama pendidikan, yaitu guru. Guru dan sekolah lebih banyak didudukkan sebagai pelaksana dari kurikulum tersebut. Kondisi itu sekaligus menunjukkan bahwa kurikulum 2013 masih bersifat sentralistik. "Memang tidak sentralistik mutlak. Tapi ini bisa membawa kelemahan dan ketidakefektifan dalam kerangka keBhinekaan" (Wuryadi, Suara Merdeka, 22/05/13).

Berdasarkan pendapat $\mathrm{di}$ atas, mungkin dapat disepakati adanya dinamisasi kurikulum. Namun demikian, dinamisasi kurikulum tersebut 
diharapkan memperhatikan kebutuhan dasar bangsa, yaitu kebutuhan bangsa dan budaya, kebutuhan subyek didik, kebutuhan lembaga yang mendidik dan pemerintah serta kebutuhan atas ilmu pengetahuan dan teknologi.

Penerapan kurikulum 2013 yang mulai dilaksanakan oleh Kementerian Pendidikan dan Kebudayaan di sekolah pada tahun pelajaran 2013 2014, tidak diikuti oleh Kementerian Agama RI dimana penerapan kurikulum 2013 di madrasah dimulai pada tahun pelajaran 2014-2015. Kebijakan ini diambil oleh Kementerian Agama karena alasan bahwa kesiapan guru untuk menghadapi perubahan kurikulum 2013 ini perlu dipersiapkan secara matang, sehingga guru di madrasah sudah mempersiapkan dirinya selama satu tahun untuk memasuki tahun pelajaran baru 2014-2015 dengan kurikulum yang baru yaitu kurikulum 2013.

Pendidikan merupakan faktor utama yang menentukan kemajuan suatu masyarakat. Dengan pendidikan bisa membangun peradaban masyarakat yang baik dan membina generasi penerus suatu bangsa. Sebagaimana diungkapkan AJ Husain Sulaiman Qurah sebagai berikut:

\section{.ijljboit)! ell; J-iSl 4j>jJI jjik. If n J}

Artinya: Sesungguhnya pendidikan merupakan salah satu faktor yang paling penting dalam menggapai kemajuan di tengah masyarakat. Dan warga negara yang baik adalah warga yang mampu memandirikan generasinya. Dan tidak diragukan lagi bahwa pendidikan mampu membimbing generasi untuk menjadi pribadi yang mandiri (Qurah, 1979: 11).

Sejarah perkembangan kurikulum di Indonesia, telah mengalami perubahan sejak Indonesia merdeka sebanyak sebelas kali yaitu; 1947, 1952, 1964, 1968, 1975, 1984, 1994, Suplemen Kurikulum 1999, KBK (2004), Kurikulum Tingkat Satuan Pendidikan, (KTSP) Tahun2006 (Idi, 2011).

Pengembangan kurikulum, dilakukan dengan cara memaksimalkan implementasi kurikulum, yang mengarah pada empat pilar pendidikan, yaitu learning to know, learning to do, learning to live together dan learning to be (Djohar, 2003: 30).

Sehingga diharapkan akan semakin mendekatkan tujuan dan misi pendidikan dalam menyiapkan sumber daya manusia yang berkualitas dan menjadi suatu kenyataan.

Penelitian tentang Implementasi Kurikulum 2013 pada Madrasah Tsanawiyah Negeri Model Makassar dianggap penting, karena Madrasah Tsanawiyah Negeri Model Makassar secara refresentatif dianggap penulis dapat mewakili MTs yang ada di Sulawesi Selatan untuk mendapatkan gambaran implementasi kurikulum 2013 oleh guru MTs di Sulawesi Selatan. Adapun permasalahan yang difokuskan pada penelitian ini adalah bagaimana Implementasi Kurikulum 2013 pada Madrasah Tsanawiyah Negeri Model Makassar."? focus masalah tersebut di breakdown dalam beberapa subpermasalahan: bagaimana Konsep Kurikulum 2013?; bagaimana Pemahaman guru Madrasah Tsanawiyah Negeri (MTsN) Model Makassar terhadap Kurikulum 2013?; dan apa saja faktor pendukung dan penghambat implementasi Kurikulum 2013 pada Madrasah Tsanawiyah Negeri (MTsN) Model Makassar dan bagaimana solusinya?

\section{Tinjauan Pustaka}

Istilah kurikulum (curriculum) menurut Toto Ruhimat dkk. berasal dari kata curir (pelari) dan curere (tempat berpacu), dan pada awalnya digunakan dalam dunia olahraga. Pada saat itu kurikulum diartikan sebagai jarak yang harus ditempuh oleh seorang pelari mulai dari start sampai finish untuk memperoleh medali/penghargaan. Kemudian, pengertian tersebut ditetapkan dalam dunia pendidikan menjadi sejumlah mata pelajaran (subject) yang harus ditempuh oleh seorang peserta didik dari awal sampai akhir program pelajaran untuk memperoleh penghargaan dalam bentuk ijazah (Ruhimat, dkk. 2011:2).

Menurut Oemar Hamalik kurikulum adalah curriculum is interpreted to mean all of the organized courses activities, and experiences which pupils have under the direction of school, whether in the classroom or not. (Kurikulum tidak terbatas pada sejum lah mata pelajaran, namun meliputi segala sesuatu yang dapat mempengaruhi perkembangan peserta didik, seperti bangunan sekolah/ madrasah, alat pembelajaran, perlengkapan sekolah/madrasah, perpustakaan, karyawan tata usaha, gambar-gambar, halaman sekolah/ madrasah, dan lain-lain) (Hamalik, 2007: 10).

Berdasarkan pengertian kurikulum tersebut di atas, dapat dijelaskan bahwa kurikulum adalah sejumlah mata pelajaran yang tertuang dalam sejumlah materi (SK-KD) yang harus dipelajari oleh peserta didik sampai akhir program sesuai dengan 
pala madrasah, wakil kepala madrasah bagian kurikulum, dan guru-guru di Madrasah Tsanawiyan Negeri Model Makassar, untuk mendapatkan informasi terkait; dokumentasi; triangulasi merupakan teknik pengumpulan data yang bersifat menggabungkan dari berbagai teknik pengumpulan data dan sumber data yang telah ada (Sugiyono, 2007: 330).

Metode ini digunakan peneliti karena pada saat pengambilan data pertama dan kedua, peneliti menemukan adanya perbedaan data, sehingga untuk mendapatkan data yang akurat peneliti melakukan wawancara langsung kepada Kepala Madrasah dan guru yang berbeda dengan sumber yang lain. Dengan demikian, setelah peneliti melakukan konfirmasi secara berulang kali, maka peneliti menemukan kesimpulan tentang kevalidan data yang diperoleh, dan data tersebut dianggap telah jenuh.

Penelitian kualitatif ini dianalisis dengan tiga cara yaitu: reduksi data, yaitu memilih dan mengambil data, mana yang akan digunakan dalam analisis data. Dalam kegiatan ini peneliti memilah data untuk mendapatkan data yang orisinil untuk dianalis. Penyajian data; karena penelitian ini adalah penelitian kualitatif, maka penyajian data bisa dilakukan dalam bentuk uraian singkat, dan sejenisnya dan yang paling sering digunakan untuk menyajikan data dalam penelitian kualitatif adalah dengan teks yang bersifat naratif (Sugiyono, 2007: 249).

Oleh karena itu dalam penyajian data ini dilihat dari jenis dan sumbernya, termasuk keabsahannya, dan dalam penyajian data. Akan tetapi yang paling utama dalam penyajian data dari hasil penelitian ini yaitu dilakukan dalam bentuk uraian singkat dan teks naratif. Terakshir melakukan verifikasi data ini adalah upaya yang dilakukan peneliti untuk mendapatkan keabsahan data, apakah dapat dipercaya keasliannya atau tidak. Dalam verifikasi data diperioritaskan kepada keabsahan sumber data dan tingkat objektivitasnya serta adanya saling keterkaitan antara data dari sumber yang satu dengan sumber yang lainnya, dan selanjutnya ditarik suatu kesimpulan.

\section{PEMBAHASAN}

\section{Konsep Kurikulum 2013 pada Madrasah Tsanawiyah Negeri Model Makassar}

Di era globalisasi yang penuh tantangan dan ketidak pastian, dibutuhkan pendidikan yang dirancang berdasarkan kebutuhan madrasah. Untuk kepentingan tersebut, kurikulum 2013 yang diharapkan pemerintah sekarang dapat dijadikan sebagai acuan dan pedoman untuk mengembangkan berbagai ranah pendidikan (sikap, pengetahuan, dan keterampilan).

Konsep kurikulum 2013 menekankan pada pengembangan kemampuan untuk menyelesaikan tugas-tugas dengan standar kemampuan dan keterampilan guru, sehingga menimbulkan motivasi belajar bagi peserta didik untuk memahami materi yang disajikan oleh guru. Kurikulum 2013 merupakan strategi pengembangan kurikulum untuk mewujudkan madrasah yang efektif, produktif, dan berprestasi.

Untuk menggambarkan bagaimana implementasi kurikulum 2013 pada madrasah Tsanawiyah Negeri Model Makassar, di bawah ini peneliti memaparkan hasil penelitian pada MTsN Model Makassar sebagai berikut:

\section{Standar Kompetensi Lulusan Kurikulum 2013}

Berdasarkan pengamatan yang peneliti lakukan kepada informan nomor 2 s/d 3, diperoleh data bahwa guru belum memiliki dokumen tentang Standar Kompetensi Lulusan (SKL) kurikulum 2013 khususnya oleh guru kelas VII.

Hal tersebut di atas, karena rancangan untuk kurikulum 2013 ini guru sudah tidak terlalu memperhatikan lagi secara rinci yang mana SI (Standar Isi) dan yang SKL, karena buku ajar untuk guru dan buku materi pelajaran untuk peserta didik sudah disusun langsung oleh BSNP sehingga di dalam pemikiran guru sekarang adalah bagaimana mendapatkan materi tersebut untuk selanjutnya diimplementasikan.

Berdasarkan hasil wawancara penulis dengan salah seorang informan an. Sy., dengan pertanyaan bahwa "apakah saudara sudah memahami SKL mata pelajaran bahasa Indonesia yang saudara ampuh"? Jawaban yang diberikan bahwa sampai saat ini belum ada, karena buku pedoman guru saja yang digunakan sekarang untuk mengajar dikelas hanya diperoleh melalui fotokopi dari teman-teman guru.

Senada dengan jawaban tersebut di atas, disampaikan pula oleh $\mathrm{Rf}$, bahwa sampai saat ini implementasi Kurikulum 2013 terkhusus dalam memahami SKL ini belum maksimal, karena buku ajarnya belum ada.

\section{Standar Isi}

Berdasarkan hasil wawancara peneliti dengan guru Ma, bahwa "terus terang masih tetap belajar terus tentang materi Kurikulum 2013 ini, karena 
masih proses apalagi buku dari pusat belum ada," seharusnya buku yang merupakan bahan ajar didik sudah harus ada sebelum memasuki tahun pelajaran baru, akan tetapi sampai saat ini belum ada.

Penjelasan serupa disampikan oleh Dm, bahwa sampai saat ini (pada saat wawancara dilaksanakan), guru-guru hanya belajar secara otodidak saja dalam memahami materi Kurikulum 2013 ini.

\section{Standar Proses}

Sesuai Peraturan Menteri Pendidikan Nasional RI nomor 41 tahun 2007 tentang standar proses untuk satuan pendidikan dasar dan menengah, menghendaki proses pembelajaran harus diawali dari perencanaan, pelaksanaan dan evaluasi. Namun demikian, berdasarkan hasil wawancara peneliti dengan Kepala Madrasah Tsanawiyah Negeri Model Makassar, bahwa sampai pada saat wawancara ini dilakukan proses tersebut belum berjalan sesuai dengan kehendak Kurikulum 2013.

\section{Standar Penilaian}

Berdasarkan Permendiknas RI Nomor 20 Tahun 2007 tentang Standar Peni laian, bahwa tujuan ditetapkannya Standar Penilaian Pendidikan yaitu dalam rangka mengendalikan mutu hasil pendidikan sesuai standar nasional pendi dikan yang di kembangkan oleh BSNP. Sedangkan ujian sekolah/ madrasah adalah merupakan kegiatan pengukuran pencapaian kompetensi yang dilakukan oleh satuan pendidikan untuk memperoleh pengakuan atas prestasi belajar dan merupakan salah satu persyaratan kelulusan dari satuan pendidikan.

Untuk mengukur ketercpaian kompetensi peserta didik pada MTsN Model Makassar dalam Kurikulum 2013 ini belum dilaksanakan karena kelas VIII yang sedianya dilaksanakan pada tahun pelajaran 2013-2014 yang lalu belum dilaksanakan oleh MTsN Model, sehingga pengukuran itu belum dilaksanakan.

\section{Pemahaman Guru Madrasah Tsanawiyah Negeri (MTsN) Model Makassar terhadap Kurikulum 2013}

Kurikulum pada prinsipnya memiliki dua sisi yang sama pentingnya, yakni kurikulum sebagai dokumen dan kurikulum sebagai implementasi. Kurikulum sebagai dokumen melahirkan bentuk kurikulum tertulis, yang kemudian dijadikan pedoman bagi setiap pengembang kurikulum termasuk guru.

Kurikulum sebagai implementasi adalah realitas dari pelaksanaan kurikulum operasional di lapangan, yang tidak lain adalah proses pembelajaran yang dilaksanakan oleh peserta didik baik di dalam maupun di luar kelas.

Pelaksanaan kurikulum tidak terpisahkan dengan kualitas guru sebagai aktor utama yang berperan sebagai pelaksana kurikulum yang diharapkan dapatmelaksanakan prosespembelaj aran di madrasah dengan sebaik mungkin agar dapat mencapai hasil sebagaimana yang diharapkan. Oleh karena itu, sebagai pendidik di madrasah, guru dituntut untuk memiliki kompetensi yang memadai baik kompetensi pedagogik, profesional, kepribadian dan sosial.

Untuk menggambarkan pemahaman guru Madrasah Tsanawiyah Negeri (MTsN) Model Makassar terhadap kurikulum 2013 di bawah ini hasil wawancara dengan informan sebagai berikut:

\section{Menyusun Program Tahunan}

Berdasarkan pengamatan langsung pada informan, ditemukan bahwa guru MTsN Model Makassar untuk kelas VIII, belum memiliki program tahunan. Data ini diperkuat dari hasil wawancara peneliti dengan Jsk.

Berdasarkan penjelasan di atas, menunjukkan bahwa guru-guru kelas VII dan VIII MTsN Model Makassar belum menyusun Program Tahunan untuk kurikulum 2013. Data ini sesuai dengan hasil pengamatan peneliti pada tidak adanya dokumen program tahunan pada perangkat pembelajaran yang ada.

\section{Menyusun Program Semester}

Program semester merupakan lanjutan dari program tahunan, yang termasuk program yang belum di buat oleh guru-guru kelas VII pada madrasah Tsanawiyah Negeri Model Makassar.

\section{Menyusun Silabus \& RPP sesuai SI ( KI. 1, 2,3,4)}

Sesuai hasil wawancara peneliti dengan Kepala Madrasah Tsanawiyah Negeri Model Makassar diperoleh data bahwa penyusunan silabus pada MTsN Model Makassar belum dilakukan oleh guru-guru kelas VII dan VIII. Hal ini disebabkan 
oleh karena bahan ajar pada kurikulum 2013 dalam bentuk buku tanpa memperhatikan berapa Kompetensi Dasar yang tertuang dalam Kompetensi Inti $(1,2,3,4)$.

\section{Proses pembelajaran}

Proses pembelajaran dalam implementasi kurikulum 2013 dapat diungkapkan melalui wawancara dengan beberapa informan yaitu:

Rf, bahwa pada tahun pelajaran 20142015 ini sudah harga mati bagi madrasah untuk mengimplementasikan kurikulum 2013, dan MTsN Model Makassar, sebenarnya melakukan persiapan dalam pelaksanaan kurikulum 2013, namun ketika memasuki tahun pelajaran 2014-2015, buku pegangan guru sebagai bahan ajar dan buku pegangan peserta didik sebagai materi ajar, sampai saat ini belum ada dari pusat, sehingga guru-guru khususnya guru kelas VII, dalam mengimplementasikan kurikulum 2013 ini hanya berusaha sendiri dengan memfotokopi materi yang diperoleh dari teman-temannya sesama guru, atau mendownlod di Internet, sehingga untuk kurikulum 2013 ini pemahaman guru dalam kurikulum 2013 ini belum maksimal, sehingga proses pelaksanaanya tadi tidak berjalan secara maksimal pula. Seahrusnya antara buku ajar guru dan materi ajar peserta didik harus ketemu.

Dm, bahwa kurikulum 2013 pada kelas VII sudah diimplementasikan, akan tetapi yang diperioritaskan sekarang adalah kelas akselerasi (2 kelas) karena guru-guru pada kelas VII yang reguler masih meminta toleransi sampai bulan September 2014 menggunakan KTSP, karena alasan untuk mempersiapkan bahan ajar sambil menunggu buku yang akan dikirimkan oleh Kemendikbud. RI. Penjelasan Dm. ini mendukung pernyataan Kepala MTsN Model Makassar, bahwa kurikulum 2013 di madrasahnya belum berjalan secara maksimal, karena kesiapan guru untuk merubah "mindset" untuk menghadapi perubahan yang paling sulit dihadapi sekarang. Selain itu Dm menjelaskan bahwa, guru-guru di MTsN Model Makassar dalam memahami kurikulum 2013 kebanyakan belajar secara otodidak saja.

Sy, menjelaskan bahwa kesiapannya sebagai guru kelas VII dalam mengimplementasikan kurikulum 2013 masih pada rentang $65 \%$. Dia mengatakan bahwa sekarang masih sementara belajar, materi bahasa Indonesia pada kurikulum 2013 ini bertambah dan jam tatap muka juga bertambah dari $5 \mathrm{Jp}$, menjadi $6 \mathrm{fP} /$ pekan. Kemudian pada saat peneliti menanyakan jumlah Kompetensi Dasar bahasa Indonesia untuk kelas VII yang diampuh, ternyata tidak dihafal.

Mr, selaku guru IPS terpadu pada kelas VII, mengatakan bahwa terus terang saya masih tetap belajar terus tentang materi Kurikulum 2013, karena masih proses apalagi buku dari pusat belum ada yang seharusnya buku ajar itu sudah ada sebelum memasuki tahun pelajaran baru tahun 2014-2015. Jadi kami guru masih inisiatif sendiri, karena seharusnya bahan ajar sudah ada untuk dipelajari guru, tapi sampai sekarang belum ada yang sampai di madrasah. Selain itu, sarana pembelajaran juga belum ada, misalnya LCD, buku pegangan guru, dan buku siswa juga belum ada.

Jk, selaku guru Sejarah Kebudayaan mengatakan bahwa untuk kelas VIII MTsN Model Makassar masih menggunakan KTSP dalam proses pembelajaran tahun pelajaran 2014-2015.

\section{Faktor pendukung dan penghambat Implementasi Kurikulum 2013 pada Madrasah Tsanawiyah Negeri (MTsN) Model Makassar dan bagaimana solusinya. \\ Faktor pendukung:}

Kepala MTsN Model Makassar sudah mengadakan pelatihan sehari terhadap gurugurunya yang mengajar di kelas VII dengan menghadirkan pemateri dari Jakarta. Selain itu, rencananya akan mengaktifkan MGMP dalam rangka mendalami materi kurikulum 2013.

Wakamad. Bagian Kurikulum, cukup proaktif dalam memfasilitasi semua guru-guru kelas VII sekalipun hanya dengan menfotocopy bahan ajar yang diperoleh dari berbagai pihak.

Guru-guru pada MTsN Model Makassar, sudah memiliki kualifikasi ijazah SI, bahkan sudah banyak yang berkualifikasi S2.

\section{Faktor penghambat:}

Pelatihan yang dilaksanakan oleh Kepala Madrasah sangat singkat (1 hari), sehingga pemahaman guru terhadap kurikulum 2013 tidak maksimal.

Buku pegangan guru dalam bentuk bahan ajar dan buku pegangan peserta didik sebagai materi ajar belum ada, sehingga pihak madrasah dan guru sangat terkendala untuk mengimplementasikan kurikulum 2013 ini

Sarana dan prasarana pembelajaran masih sangat terbatas, sehingga guru-guru kurang maksimal untuk melakukan variasi- variasi dalam 
proses pembelajaran.

Merubah "Mindset" dalam cara berpikir guru merupakan kendala yang sangat berat, karena paradigma yang sudah terbangun dalam diri seorang guru membentuk karakter yang susah untuk berubah dalam waktu yang singkat.

\section{Solusi dalam mengatasi Hambatan Implementasi Kurikulum 2013 pada MTsN Model Makassar}

Solusi yang terbaik bagi MTsN Model Makassar dalam mengatasi hambatan Implementasi kurikulum 2013 adalah dengan mengatasi seluruh hambatan yang ada diantaranya pelatihan penyusunan program perencanaan pembelajaran, pelatihan melaksanakan proses pembelajaran, dan melengkapi sarana prasarana pembelajaran

\section{PENUTUP}

Konsep Kurikulum 2013 pada MTsN Model Makassar berdasarkan pengamatan yang dilakukan, diperoleh data bahwa guru belum memiliki dokumen tentang Standar Kompetensi Lulusan (SKL) kurikulum 2013 khususnya oleh guru kelas VII. Hal tersebut di atas terjadi, karena rancangan kurikulum 2013 bagi guru sudah tidak terlalu diperhatikan lagi, karena buku ajar untuk guru dan buku materi pelajaran untuk peserta didik sudah disusun langsung oleh BSNP. sehingga di dalam pelaksanaannya guru sekarang adalah bagaimana mendapatkan materi tersebut untuk dijadikan sebagai pedoman untuk mengajar.

Terkait dengan pemahaman guru MTsN Model Makassar terhadap kurikulum 2013 berkaitan dengan Standar Kompetensi Lulusan, bahwa sampai saat ini belum difahami secara menyeluruh, dikarenakan buku pedoman yang digunakan untuk mengajar masih menggunakan buku panduan dalam bentuk fotokopi. Untuk mengukur ketercapaian kompetensi peserta didik pada MTsN Model Makassar dalam Kurikulum 2013 ini belum dilaksanakan karena kelas VIII yang sedianya dilaksanakan pada tahun pelajaran 2013-2014 yang lalu belum dilaksanakan oleh MTsN Model, sehingga pengukuran itu belum dilaksanakan.

Implementasi kurikulum 2013 tidak terlepas dari dukungan seluruh komponen MTsN Model Makassar, sebaliknya hambatan bagi impelemtasi kurikulum tersebut yakni kurangnya pelatihan dinternal madrasah, ketersediaan buku pegangan, sarana dan prasarana pembelajaran, dan secara umum berpikir guru. Solusi terhadap hambatan Implementasi kurikulum 2013 oleh madrasah dilakukan pelatihan penyusunan program perencanaan pembelajaran, pelatihan melaksanakan proses pembelajaran, dan melengkapi sarana prasarana pembelajaran.

\section{Ucapan Terima Kasih}

Tulisan yang ada ditangan pembaca ini tidak terlepas dari batuan berbagai pihak terutama penulis haturkan terimakasih kepada seluruh civitas MTsN Model Makassar Bapak Kepala Sekolah berserta guru MTsN Model Makassar yang telah menerima penulis untuk melakukan penelitian ini. Kepada Tim Redaksi Al Al-Qalam atas diterimanya tulisan ini.

\section{DAFTARPUSTAKA}

Abdullah Idi. 2011. Pengembangan Kurikulum Teori \& Praktik. Cet. I; Jogjakarta: Penerbit, ArRuzz Media.

Djohar. 2003. Pendidikan Strategik, Alternatif untuk Pendidikan Masa Depan Yogyakarta: LESFI.

Hamalik, Oemar. 2007. Manajemen Pengembangan Kurikulum, (Cet. Kedua; Bandung: PT. Remaja Rosdakarya.

Kemendikbud. RL, Bahan Sosialisasi Kurikulum 2013.

$\mathrm{Ng}$ Pak Tee. 2005. The Learning School, Innovation and Enterprise. Singapore: Copyright by Pearson Education South Asia.

Permendiknas RI Nomor 20 Tahun 2007 tentang Standar Penilaian Pendidikan Dasar dan Menengah, Jakarta, 2007

Permendiknas RI Nomor 20 Tahun 2007 tentang Standar Penilaian, Jakarta, 2007.

Ruhimat, Toto. dkk. 2011. Kurikulum \& Pembelajaran. Cet. Ke I; Jakarta: PT. Raja Grafindo Persada.

Santosa, Eri B, widyaiswara Lembaga Penjaminan Mutu Pendidikan (LPMP) Daerah Istimewa Yogyakarta: http://m.suaramerdeka. com., diunduh 18 Desember 2012.

Santoso, Prio Budi (anggota DPR RI (Golkar)), Tribun, tgl 24 Mei 2013.

Sugiyono. 2007. Metode Penelitian Administrasi Dilengkapi dengan Metode $R \& D$, Cet. XV; Bandung: Alfabeta.

Sulaiman Qurah, Husain. 1979. al-Usul al-Tarbiyyah fi al-Bind al-Manahij. Ttp.

Undang-Undang RI. Nomor No. 14 Tahun 2005

Wuryadi, suaramerdeka.com, 22 Mei 2013. 